\title{
HUMAN CAPITAL DEVELOPMENT AND ECONOMIC DEVELOPMENT IN NIGERIA
}

\section{Raymond Minini ${ }^{1}$ and Ekponaanuadum Nwinee ${ }^{2}$}

\author{
Department of General Studies, School of Foundation and General Studies, Captain Elechi \\ Amadi Polytechnic, Rumuola, Port Harcourt \\ ${ }^{1}$ Email: raymondminini@yahoo.com \\ 2Email: nwineekpo4@gmail.com
}

Cite this article:

Raymond M.,

Ekponaanuadum N. (2021), Human Capital Development and Economic Development in Nigeria. African Journal of Economics and Sustainable Development 4(1), 32-44. DOI: $10.52589 / A J E S D-$ SZ87BDFR.

\section{Manuscript History \\ Received: 10 April 2021 \\ Accepted: 29 April 2021 \\ Published: 11 May 2021}

Copyright $\odot 2020$ The Author(s). This is an Open Access article distributed under the terms of Creative Commons AttributionNonCommercial-NoDerivatives 4.0 International (CC BY-NC-ND 4.0 ), which permits anyone to share, use, reproduce and redistribute in any medium, provided the original author and source are credited.
ABSTRACT: This paper set out to investigate the impact of human capital development on the drive to achieving economic development in Nigerian. It adopted the Ex-post facto research design as the variables-Misery Index, GEH and GEE cannot be manipulated as they have previously occurred. The study span for a period of 38 years which covered from 1981 - 2018. Secondary data sourced from the statistical bulletin of the Central Bank of Nigeria and the world development index of the World Bank was utilized for this study. The study employed the ordinary least square (OLS) method and the Error Correction Model estimation technique to examine the long run relationship and short run dynamics of the variables. The result of the Johansen cointegration test established the presence of long run relationship between misery index, pupil teacher ratio, government spending on education and health. The result of the ordinary least square revealed a negative and significant relationship between misery index and pupil teacher ratio in the long run. The results of the short run analysis revealed that current level of pupil teacher ratio impact on the misery index in Nigeria negatively and significantly. Informed by the discoveries, the study proposed the recruitment of more teachers to improve the current pupil teacher ratio in the country and also increase the budgetary allocation to the education sector.

KEYWORD: Human Capital Development, Economic Development, Pupil Teacher Ratio, Misery Index, Government Expenditure on Education, Government Expenditure on Health 


\section{INTRODUCTION}

Economists are of the position that for a State to progress politically and socio-economically, the human capacity needs to be developed. In other words, it is imperative to say that the varying differences in development noticeable among countries rests on the substructure of not the God's given resources and capital accumulation of the country, but on both the quantity and quality of its human resource.

Education is then, the key that unlocks all the forces of economic growth and development of a nation. This fact is inline with Todaro (1980), Wilson (2017) when they cited Prof. Harbison, $\mathrm{H}$ that human resource constitutes the ultimate basis for the wealth of nations. Capital and natural resources are passive factors of production, human beings are the active agents who accumulate capital, exploit natural resources, build social, economic and political organizations and carry forward national development. As pointed out by Harbison (1971) "Clearly a country which is unable to develop the skills and knowledge of its people and to utilize them effectively in the national economy will be unable to develop anything else" but the question is how can one be able to develop the skills and knowledge required of the people while trained and qualified teachers are what they are now, and in short supply in the economy? Nigeria has a shortage of 2777,537 teachers in basic education sector as pointed out by the Executive Secretary, Universal Basic Education Commission,,Dr Hamid Bobboyi ,News agency of Nigeria(2021). Teachers really are in short supply not because there are no teachers in the country; we quite know that the turnover by the training institutions is high but they tend to leave the teaching profession if and when more attractive jobs become available in Government, politics or private enterprises.

This ugly situation according to Meier (1978) is the master bottleneck that retards the entire process of human resource development. If this situation is allowed to continue the ones that are held back for fear of God, failure to secure first choice career, permission to moonlight, gender and so on, the result will be mass failure in examinations, incongruous laws and purchased justices, pathetic doctors that kill more than cure, unimaginative engineers that will construct bridges that will collapse, roads with pot holes and power that will always fail.

This paper is therefore evaluating the impact of human capital development to the economic development in Nigeria.

\section{LITERATURE REVIEW}

\section{Review of Conceptual Issues}

\section{Concept of Economic Development}

Economic development has been a victim of definitional pluralism and taken as identical to economic growth in some quarters or cases. Economic development is a difficult term to define and it is a ubiquitous held view that economic development is a complex concept as an array of interpretations is ascribed to it by the plethora of schools of thought in the social sciences arena and beyond.

It can be viewed, for instance, as economic growth. That is the achievement of yearly increases in both the total and per capita output of goods and services (Wilson, 2017) citing 
Akpakpan (1987). In other words, any country that was able to achieve on a sustained basis an annual increase in its Gross National Product at the rate of between 5 and 7 percent would be described as developing.

It can also be viewed in terms of a country's level of industrialization. For instance, if the share of industrial output in total domestic output was rising, then that country is said to be developing.

Gboyega (2003) sees economic development as an idea that embodies varying attempts to raise the conditions of human existence in all facets. It suggests an improvement in the material wellbeing of the citizen of a country or State, and not the highly placed only, in a sustainable way that present consumption does not impede future consumption. It also stresses that poverty and inequality be drastically removed or ebbed.

Currently, most economists and social scientists have conceived development as a multidimensional phenomenon having economic, social, political, technological and many other dimensions. It is also very important in the discussion of the quality of life of people today to includes environmental issues such as pollution, environmental degradation and not just growth in per capita income, because of the externality effect of production and consumption.

According to Umo (2007), the production and consumption activities most times result in environmental damage in the form of pollution, warming of the environment and so on.

In other words, there is need to protect the environment to avoid the persistence of poverty, unemployment inequality and health hazards because they are directly connected to the mismanagement of the environment. Hence, this paper will adopt with little addition, the definition of Akpakpan (1987 and 2011) as cited by Wilson (2017). That is, development is the process of improvement in the various aspects of the life of the society, usually seen in the occurrence of desirable changes such as;

i. an increase in the capacity of the society to produce and distribute needed goods and services.

ii. a reduction in the level of unemployment; that is, a reduction in the proportion of the population living below the poverty line;

iii. a reduction in the level of economic and social inequality;

v. an increase in real output of goods and services, that is, economic growth;

vi. a rise in the levels of social and political consciousness and political participation;

vii. an improvement in the quality of services;

viii. an improvement in the quality of life as measured by access to clean and safe water, adequate health services and decent accommodation;

ix. a reduction in pollution and or environmental degradation. 


\section{Concept of Human Capital Development}

Todaro and Smith (2011) states that human capital is the productive investments embodied in human persons, including skills, abilities, ideas, health and locations, often resulting from expenditures on education, on - the - job training programmes and medical care. Becker (1967) refers to it as the abilities and qualities of people that make them productive, knowledge to him is the more important of these, although other factors like a sense of punctuality to the state of someone's health, also matter.

As construed by the organization of economic co-operation and development (OECD), it is the aptitude, abilities, versatility, and other features encapsulated in people that are noteworthy to productive activities (OECD, 1998).

As perceived by Gbosi (2007), manpower is the level of aptitude and efficient talents imbedded in an individual that plays in the arena of production.

Human capital development which is conterminous with human capital formation, human resource development, investment in human capital, on the other hand refers to the process of acquiring and increasing the number of persons who have skills education and experience which are critical for economic and political development of a country, Wilson (2017).

Human capital development according to Okojie (1995) refers to the process of acquiring and increasing the number of persons who have the skills, education and experience that are cited for economic growth and development of country's economy. For Habison (1973), it is the deliberate and continuous process of acquiring requisite knowledge, skills and experiences that applied to produce economic value for suitable national development.

It can be achieved through various ways such as;

i. Provision of organized formal education at the primary, secondary and tertiary levels.

ii. Provision of on-the-job training

iii. Migration of individuals and families

iv. Provision of health facilities and services which affect life expectancy, strength, stamina, vigour and vitality of the people.

\section{Pupil- Teacher Ratio}

Pupil- teacher ratio is the average number of pupils or students per teacher at a specific level of education in a given school - year. It is obtained by dividing the total number of pupils enrolled at the specific level of education by the number of teachers teaching predominantly at that level. A high pupil-teacher ratio suggests that each teacher has to be responsible for a large number of people. In other words, the higher the pupil-teacher ratio, the lower the relative access of pupils to teachers.

It is generally assumed that a low pupil-teacher ratio signifies small classes, which enables the teacher to pay more attention to individual students, which may in the long run result in a better performance of the pupils. 
The national average public students school teachers stipulates that the pupil teacher ratio should be UNESCO Institute for Statistics, (2006) 40:1. Significantly pupil teacher ratios are very essential to quality education. They perhaps rank alongside professional knowledge, skill, as well as strategies, in genuinely educational success and performance.

\section{Misery Index}

The misery index is an indicator, created by an economist Arthur Okun, that is used to determine how economically well off the citizens of a country are. It is the sum of the unemployment and underemployment rate and the inflation rate of a particular period.

These factors are important because they pose economic and social costs to the average income earner. Any increase in the misery index is triggered by an increase in either of the variable and signifies economic discomfort and negative consumer sentiment. If this movement persists, consumers will be hit hard. There will be dwindling purchasing power the poor will become poorer, declining economic activity and reduce consumption. In the end, the citizen will be left with high uncertainty and low morale. Halton (2019).

\section{Review of Theoretical Literature}

\section{The Human Capital Theory}

Schultz (1961) laid the ground for this theory which was later advanced by Becker, a Nobel prize winner in economics, in 1964 in his work on the economics of employer-provided training. The theory posits that the education or training of workers increase their productivity and income level as it raises their skills level and knowledge. In driving home, the main dictum of the theory, Becker (1967) categorized human capital into specific and general for which a clear distinction was made available. According to Becker (1967), specific human capital arises when workers acquire knowledge directly tied to their firms, such as how to use proprietary software. Companies are happy to pay for this kind of training since it is not transferable.

On the other hand, general human capital bothers on the expertise acquired through training and education for which its application is across all facets of productive engagement (writing and reading skills fall into this category). Companies are often reluctant to go for this, because they may well jump ship to whichever company pays them most.

In Becker (1967) train of thought, human capital bears similarities with the traditional factors of production like property, plant and equipment. As such funds can be invested in the development of human capital through training, education, provision of quality health care, and the level of total output, like the tangible investment in capital, varies partially with the rate of return on human capital owned. In this sense, human capital can be classified as a factor of production for which continuous investment results in increasing level of output.

\section{Review of Empirical Literature}

Jaiyeoba (2015) empirically investigated the relationship between investment in education, health and economic growth in Nigeria, using time series data from $1982-2011$. The paper employed trend analysis, the Johansen cointegration and Ordinary Least Square techniques. The findings indicated that there is a long run relationship between government expenditure on education, health and economic growth. The variables - health and education expenditure, 
secondary and tertiary enrolment rate and fixed capital formation with the expected positive signs and also statistically significant according to the paper have strong implications on education and health policy and recommended that in order to accelerate growth and liberate Nigerian from the vicious circle of poverty, the government should put in place policies geared towards massive investment in the education and health sectors.

Uduh and Benedict (2017) examined the impact of Nomadic education expenditure and economic growth in Nigeria. The study made use of time series data on real domestic product and total government expenditure on Nomadi education from 1986 - 2012 and employed Ordinary Least Square (OLS) which provides information about the long-run relationship between the variables. It also revealed that total government expenditure on nomadic education has significant impact on Nigeria economic growth. It therefore recommended that the government should increase her budgetary allocation to the Normadic education and other educational sectors because adequate investment in this sector will improve educational outcome and induce the nation's economic growth.

Eigbiremolen \& Anaduaka (2014) employed the augmented solow human capital growth model on national output, a proxy for economic growth, using quarterly time series data from 1999 - 2012. Empirical results showed that human capital development in line with theory, exhibits significant positive impact on output level. Meaning that human capital development is indispensable in the achievement sustainable economic growth in Nigeria. The result further revealed a relatively inelastic relationship between human capital development and output level. The study therefore recommended that government and policy makers should make concerted and sincere efforts in building and developing human capital through adequate educational funding across all levels.

Ogunleye, Owolabi, Sanyaolu and Lawal (2017) employed the Ordinary Least Square (OLS) regression analysis to examine the impact of human capital development on economic growth in Nigeria using annual time series data from 1981 - 2005. The empirical result showed that human capital development has significant impact on economic growth, as proxy by the gross domestic product. And that in line with theory the human capital development indicators namely secondary and tertiary school enrolment, total government expenditure on health and education exhibit positive and statistically significant impact on economic growth of Nigeria. The result further revealed that life expectancy and primary school enrolment, however, exhibited a negative and statistically insignificant impact on economic growth of Nigeria. The study therefore recommended that government should allocate adequate resources for the development of human capital in order to enhance economic growth in Nigeria.

Adeyemi and Ogunsola (2016) examined the impact of human capital development on economic growth in Nigeria, using time series data spanning from 1980 - 2013 which were sourced from the World Bank Indicators and National Bureau of Statistics. The study employed ARDL cointegration analysis to estimate the relationship among the variables used. The result revealed that there is positive long-run relationship among the secondary school enrolment, public expenditure on health, life expectancy rate, gross capital formation and economic growth but it was statistically insignificant. The results further revealed that there was negative long-run relationship among primary, tertiary school enrolment, public expenditure on health and economic growth. The study therefore recommended that government should put in place the required education and training policy that would 
guarantee quality schooling for primary and tertiary education and commit more funds to the health sector to enhance human capital development.

\section{Evaluation of Empirical Literature}

Previous works examined the nexus between human capital development, and economic growth, entrepreneurial advancement, using Gross Domestic Product (GDP) as a proxy for economic growth which is the dependent variable. Actually, economic development is a broader concept than economic growth. Growth is vital and necessary condition for economic development, but not a sufficient condition as it cannot guarantee economic development; and Government Expenditure on Education (GEE), Government Expenditure on Health $(\mathrm{GEH})$, primary school enrolment rate and tertiary school enrolment rate as independent variables.

This paper so as to emphasize the implicating dangers of unemployment to the economic development of Nigeria, especially now that there is increasing rate of unemployment and seemingly government inability to curb it. We are quite aware that the turnout of graduates had been massive but half baked and unemployable; some of them cannot even write letter of application for vacant job positions, is using misery index as measure at economic development and introducing pupil-teacher ratio; to emphasize quality instead of quantity of human capital as part of the explanatory variables in its study which is the gap it tries to fill. And in so doing, it extends knowledge in the subject area.

\section{METHODOLOGY}

The paper made use of the Ex-post facto design as the variable under investigation cannot be manipulated as they have previously occurred and the type of data utilized have been documented by research institutions like National Bureau of Statistics, World Bank, Central Bank of Nigeria, among others. The secondary data used for this inquiry was sourced from United Nations Educational, Scientific, and Cultural Organization (UNESCO) Institute for Statistics and the Central Bank of Nigeria (CBN) statistical bulletin, which made available detailed information about Nigeria's misery index (MI), pupil teachers ratio (PTR), government expenditure on education (GEE), and government spending on health (GEH). The sourced data covered a time horizon from 1981 to 2018.

\section{Model Specification}

The model adopted was anchored on the human capital theory which posits that investment in education propels economic development. The model for this study was adapted from the works of Adeyemi \& Ogunsola (2016) and Ogunleye, et al., (2017). This study modifies earlier works by employing misery index as a proxy of economic development and an introduction of pupil teacher ratio as an index of human capital. 
The modified model for this study is expressed as:

$$
\mathrm{MI}=\mathrm{f}(\mathrm{PTR}, \mathrm{GEE}, \mathrm{GEH})
$$

This can be further stated as;

$$
M I=B_{O}+B_{1} P T R+B_{2} G E E+B_{3} G E H+U_{t}
$$

The log-linear expression of the explicit forms of equations (1)is given below;

$$
\mathrm{InMI}=\mathrm{z}_{0}+\mathrm{z}_{1} \operatorname{InPTR}+\mathrm{z}_{2} \mathrm{InGEE}+\mathrm{z}_{3} \operatorname{InGEH}+\mathrm{V}_{\mathrm{t}}
$$

Where:MI= Misery Index

$$
\begin{aligned}
& \mathrm{PTR}=\text { Pupil Teacher Ratio } \\
& \text { GEE = Government Expenditure on Education } \\
& \text { GEH = Government Expenditure on Health } \\
& \mathrm{Z}_{0}=\text { constant parameters } \\
& \mathrm{Z}_{1}-\mathrm{Z}_{3}=\text { elasticities of the predictor variables } \\
& \text { In }=\text { natural log operator } \\
& \mathrm{V}_{\mathrm{t}}=\text { disturbance terms }
\end{aligned}
$$

Theoretically, the a priori expectation for each of the parameter estimates of the explanatory variables is $\mathrm{z}_{1}-\mathrm{z}_{3}<0$.

\section{Econometric Techniques}

The econometric techniques used for this study include; the ordinary least squares (OLS) method, the unit root, co-integration, and the error correction model. The unit root was used to test the order of integration of the variables as the time series ordinarily possess nonstationary attributes as their spread change show tendency of a non-constant variance. The approach used for this inquiry was the Augmented Dickey-Fuller test proposed by Dickey \& Fuller (1979).

With the confirmation of the stationarity of the series, a co-integration test is undertaken to determine if the series move together in the long run. The study adopted the Johansen (1991) cointegration technique.

Succeeding the validation of a long run co-movement, the equilibrium correction model is constructed to model dynamic relationship between the variables. The object of this estimation bothers on the exposure of short-run eccentricities that could play out in formulating the long run co-integrating equation.

The error correction model (ECM) of the log-linear model illustrated in equation 1.1 will be utilized to estimate the equilibrating speed of the model as it adjusts from short run equilibrium to long run equilibrium state. The error correction model is expressed thus; 


$$
\begin{aligned}
\Delta I n M I=z_{0} & +\sum_{i=1}^{h} z_{1} \Delta \operatorname{InMI_{t-i}}+\sum_{i=1}^{h} z_{2} \Delta \operatorname{InPTR} R_{t-i}+\sum_{i=1}^{h} z_{3} \Delta \operatorname{InGEE_{t-i}} \\
& +\sum_{i=1}^{h} z_{4} \Delta \operatorname{In} G E H_{t-i}+q E C M_{t-1}+V_{t} \ldots \ldots \ldots \ldots \ldots \ldots \ldots
\end{aligned}
$$

Where: MI, PTR, GEE, and GEH remain as defined in equation (1.1).

$\mathrm{h}=$ lag lengths for the model

$\Delta=$ first differencing operator

$\mathrm{V}_{\mathrm{t}}=$ white noise disturbance term

$q=$ coefficient of the ECM.

\section{RESULTS AND DISCUSSIONS}

\section{Table 1: Static Regression Result}

\section{Dependent variable: $\log (\mathbf{E X R})$}

\begin{tabular}{lll}
\hline Variable & Coefficient & Prob. Value \\
\hline C & $9.8751^{* * *}$ & 0.0037 \\
$\log ($ PTR $)$ & $-1.7988^{* *}$ & 0.0348 \\
$\log ($ GEE $)$ & -0.0792 & 0.7467 \\
$\log ($ GEH $)$ & 0.0910 & 0.6772 \\
\hline
\end{tabular}

R-squared $=0.137$, Prob. - f-stat $=0.1658$

Durbin- Watson stat. $=\mathbf{1 . 2 1 4}$

Source: Researcher' computation

Note: *** and ** denote significance at 1 percent and 5 percent levels respectively.

From the table above which reports the outcome of the static long-run regression analysis, it can be observed that pupil teacher ratio exerts a negative impact on misery index during the length of this study. As revealed by the outcome of the analysis, a one percent increase in the pupil teacher ratio causes the misery index to fall by 1.79 percent. Nevertheless, the impact government spending on education is negative and insignificant as the coefficient's probability value of 0.7467 is greater than the 0.05 level. In consonance with earlier submission, the amount of money expended on health by the Nigerian government causes misery index to rise as the association is positive and insignificant. The R-squared of 0.13 which reports the explanatory power of the independent variables exposes their lack of explanatory power as 13 percent impulses in MI is collectively attributed to PTR, GEE, and GEH. The probability value of F-statistics of 0.16558 shows that, taken as a whole, PTR, GEE, and GEH are insignificant in causing changes in the Misery Index of Nigeria. 
African Journal of Economics and Sustainable Development

ISSN: 2689-5080

Volume 4, Issue 1, 2021 (pp. 32-44)

www.abjournals.org

Table 2: Results of ADF Test

\begin{tabular}{lllll}
\hline Variable & Level/First/Second & $\begin{array}{l}\text { Calculated } \\
\text { ADF t-Stat }\end{array}$ & $\begin{array}{l}\text { ADF Critical } \\
\text { Value at 5\% }\end{array}$ & $\begin{array}{l}\text { Order } \\
\text { integration }\end{array}$ \\
\hline InMI & Level & -0.374983 & -1.950117 & \\
& First & -7.111390 & -1.950687 & $\mathrm{I}(1)$ \\
\hline InPTR & Level & 0.293588 & -1.950394 & \\
& First & -9.544813 & -1.950394 & $\mathrm{I}(1)$ \\
\hline InGEE & Level & -1.069535 & -2.943427 & \\
& First & -7.358942 & -2.945842 & $\mathrm{I}(1)$ \\
\hline InGEH & Level & -0.805577 & -2.945842 & \\
& First & -10.45570 & -2.945842 & $\mathrm{I}(1)$ \\
\hline
\end{tabular}

Source: Own computation using E-Views 9

Table 4.2 reports the result of the augmented Dickey-Fuller test carried out. It is evidence from the result above that; none of the variables were stationary at level. When time series data is non-stationary and used for analysis, it may give spurious results, that is, artificial and deceitful results because estimates obtain from such data will possess non-constant variance. The verdict reached is based on the material evidence that, the ADF statistics for each variable was less than their corresponding critical value at $5 \%$ level of significance. All four variables namely MI, PTR, GEE, and GEH assumed stationarity after the first difference. Conclusively, the variables of the adopted model are integrated of order one.

Table 3: Result of Johansen cointegration Test

Series: InMIInPTRInGEEInGEH

\begin{tabular}{|c|c|c|c|}
\hline Trace statistic & $\begin{array}{l}\text { Hypothesized No. } \\
\text { of CE(s) }\end{array}$ & Max-eigen statistic & $\begin{array}{l}\text { Hypothesized No. } \\
\text { of CE(s) }\end{array}$ \\
\hline $\begin{array}{l}60.61551 \\
(47.85613)\end{array}$ & None * & $\begin{array}{l}31.21034 \\
(27.58434)\end{array}$ & None * \\
\hline $\begin{array}{l}29.40517 \\
(29.79707)\end{array}$ & At most 1 & $\begin{array}{l}19.16095 \\
(21.13162)\end{array}$ & At most $1 *$ \\
\hline $\begin{array}{l}10.24422 \\
(15.49471)\end{array}$ & At most 2 & $\begin{array}{l}8.81763 \\
(14.26460)\end{array}$ & At most 2 \\
\hline $\begin{array}{l}1.42658 \\
(3.84146)\end{array}$ & At most 3 & $\begin{array}{l}1.42658 \\
(3.84146)\end{array}$ & At most 3 \\
\hline
\end{tabular}

Source: Researcher's computation

* denotes rejection of the hypothesis at 0.05 level

Figures in bracket represent critical values of Trace and Max-Eigen statistics at 5 percent level. 
The Johansen cointegration approach to long run determination was based on the trace test and maximum Eigen value test. The result of the trace test conducted revealed that there exist one cointegration equations in the model. This by inference implies the existence of a longrun association between misery index (MI), pupil teacher ratio (PTR), government spending on education (GEE), and government expenditure on health (GEH). Fluctuation in any of the series incorporated in this study' model causes other variables to exhibit identical movement through time in the long run. Similarly, the result of the Maximum Eigen test revealed the existence of one co-integrating equations. Based on the outcome of both test the study concludes that there is a common movement between MI, PTR, GEE, and GEH.

With the confirmation of long run relationship between the variables, the error correction model was constructed to capture short run dynamics that could occurred while estimating the long run model.

\section{Table 4: Parsimonious ECM Result}

\section{Dependent variable: $\mathrm{D}(\mathrm{InMI})$}

\begin{tabular}{lll}
\hline Variable & Coefficient & Prob. \\
\hline D(InPTR) & -2.0401 & 0.0167 \\
D(InPTR(-1) & -0.7891 & 0.2975 \\
D $($ InGEE $)$ & 0.1548 & 0.5052 \\
D(InGEE $(-1))$ & -0.0939 & 0.6825 \\
D $($ InGEH $)$ & -0.0231 & 0.9269 \\
D $($ InGEH(-1)) & 0.0811 & 0.7488 \\
ECM(-1) & -0.6818 & 0.0011 \\
C & 0.0075 & 0.9356 \\
\hline R-squared =0.385 & Prob. (F-Stat $)=\mathbf{0 . 0 3 9}$ & Durbin-Watson stat $=\mathbf{1 . 5 1 8}$
\end{tabular}

Source: Own Computation using Reviews 9

The result in table 4.4 documents the output of the equilibrium correction model (ECM) estimated and reveals the coefficient of determination as 0.385 . This indicates that 38 percent of total change in misery index is caused by the predictor variables in Nigeria over the period 1981 to 2018. The result divulged that misery index is impacted on negatively by the current level and first lag of pupil teacher ratio. Howbeit, current level of pupil teacher ratio is significant in influencing current misery index in Nigeria. Current government spending on education was found to positively influence current level of misery index in Nigeria and initial level of government spending on education negatively impacts on misery index. The association between current government spending on health and misery index is negative and insignificant, as the relationship between previous year's spending on health and current level of misery index in Nigeria was found to be positive and insignificant. The probability value of the f-stat of 0.039 used to measure the collective significance of the lagged variables in influencing the explained variables indicates that jointly the variables in the model significantly impact on the misery index of Nigeria (a summation of inflation and unemployment rate). The estimate of the error correction term computed to be -0.68 conform to the expectation as the coefficient is negative and significant at 0.05 level of significance. This indicates that 68 percent of short run disequilibrium are adjusted before the next period 
as the significance of the obtained coefficient showing that the speed at which the model converges to long run equilibrium is high.

\section{SUMMARY AND CONCLUSION}

By means of the ordinary least square (OLS) method and ECM approach, the study sought to investigate if the economic development of Nigeria can be propelled by means of development of human capital. The result of the ordinary least squares and ECM indicates that pupil teacher ratio have a significant negative effect on economic development in Nigeria. The result of the ECM revealed that estimated model adjust faster to restore long run equilibrium following short-run deviations, illuminating the importance of pupil teacher ratio in achieving economic development in Nigeria.

\section{RECOMMENDATIONS}

Grounded on the discoveries of this study, the following recommendations were made;

i. The Federal Government of Nigeria should improve on the pupil teacher ratio by employing more teacher in the educational sector. This is because a high pupil teacher ratio suggests that each single teacher is responsible for a large number of pupil which by implication means that a high ratio lowers the relative access of pupils to teachers. The general assumption is that, a lower ratio implies the existence of smaller classroom, thus enabling teachers to keep an eye out or have care for each pupil. The culminating effect of this is an increase in the quality of education resulting in an improvement in the general welfare of Nigerians.

ii. The study suggests an increase in the government budgetary allocation to education from the present abysmal percentage which is below 15 percent of total budget to the 25 percent prescribed by the United Nations Development Programme (UNDP).

iii. Due to the insignificant effect of health expenditure in lowering the misery index in Nigeria, the study proposed an improvement in the welfare packages of health care personnel in the country so as to prevent the mass exodus of medical doctors and other health personnel from the shores of Nigeria and improve the quality of life of Nigerians.

\section{REFERENCES}

Adeyemi, P. A., \& Ogunsola, A. J. (2016). The impact of human capital development on economic growth in Nigeria: ARDL Approach. IOSR Journal of Humanities and Social Science, 21(3), 1-7.

Akpakpan, D.E. (1987). Crossroads in Nigerian development and changes. New Generation Publishers.

Becker, G. S. (1967). Human capital and the personal distribution of income: An analytical approach (No. 1). Institute of Public Administration. 
Dickey, D. A., \& Fuller, W. A. (1979). Distribution of the estimators for autoregressive time series with a unit root. Journal of the American Statistical Association, 74(366a), 427431.

Eigbiremolen, O. G. \& Anaduaka, U. S. (2014). Human capital development and economic growth: The Nigeria experience. International Journal of Academic Research in Business and Social Sciences, 4, (4).2222 - 6990, https://dxi.doi.org/10.6007/IJARBSS/v/414/749.

Gbosi, A. N. (2007). The Nigerian economy and current economic reforms, Olorunishola Publishers.

Gboyega, A. (2003). Democracy and development: The imperative of local governance. An inaugural lecture, University of Ibadan, 6-7.

Harbison, F.H. (1973). Human resources as the wealth of nations. Oxford University Press.

Jaiyeoba, S. V. (2015). Human capital investment and economic growth in Nigeria. African Research Review, 9(1), 30-46.

Johansen, S. (1991). Estimation and hypothesis testing of cointegration vectors in Gaussian vector autoregressive models. Econometrica: Journal of the Econometric Society, $1551-1580$

Meir, G.M. (1976). Leading issues in economic development. Oxford University Press Inc.

Ogunleye, O. O., Owolabi, O. A., Sanyaolu, O. A., \& Lawal, O. O. (2017). Human capital development and economic growth in Nigeria. Journal of Business Management, 3(8), $2455-6661$.

Ogunleye, O. O., Owolabi, O. A., Sanyaolu, O. A., \&Lawal, O. O. (2017). Human capital development and economic growth in Nigeria. Journal of Business Management, 3(8), 17-37.

Okojie, C.E.E. (1995). Human capital formation for productivity growth in Nigeria, Nigerian Economic and financial review, June, $44-55$.

Schultz, T. W. (1961) Investment in human capital. The American Economic Review, 5(4), 117.

Todaro, M.P. (1980). Economics for a developing world. London Group Ltd.

Todaro, M.P. and Smith, S.C. (2011). Economic Development $11^{\text {th }}$ Ed. Pearson.

Uduh, D.M, and Beredict, C. (2017). Human capital development and economic growth in Nigeria: The role at nomadic education. International Journal of Asian Social Science, 7(11),931 - 941 .

Umoru, D., \& Odjegba, O. P. (2013). Human Capital Development and the Nigerian economy: A dynamic specification. Developing Countries Studies, 3(3), 74-85.

What is Misery Index.

https://www.proshareng.com/news/nigeriainlestopedia.om/terms/n/merseryindex.asp.

Wilson, G. (2017). Development economics: A concise Text. Pearl Publishers. 